\title{
MICROBIAL EFFECTIVENESS THROUGH VERMICOM- POSTING TECHNIQUE FOR THE BIOLOGICAL STABILIZATION OF SOLID WASTE
}

\author{
B. Baral ${ }^{1}$, N. Bhattarai' ${ }^{2}$ and G. Shrestha ${ }^{1}$
}

\section{ABSRACT}

Bacterial and fungal isolates were isolated and their effectiveness in composting on different substrates with the aid of earthworms Eisenia foetida (Red Wigglers) was performed at Nepal Academy of Science and Technology (NAST). Different parameters such as isolation of microorganisms, earthworm multiplication, composting effectiveness, analysis of micro-flora, their antimicrobial activity and nutrient content were performed. Bacteria such as Bacillus sp., Pseudomonas sp., Micrococcus sp., Azotobacter sp., Beijerinckia sp. were isolated, where as the fungal isolates include Aspergillus sp., Penicillium sp., Mucor sp., Rhizopus sp., Fusarium sp., Geotrichum sp. etc and the isolated actinomycetes were Streptomyces sp., Micromonospora sp etc. The treatment prepared by using the saw dust as a substrate and inoculation with Rhizobium sp. showed better for the earthworm multiplication, followed by biogas slurry with Rhizobium, Lantana camara with both Trichoderma and Rhizobium, Ageratina adenophora with both Trichoderma and Rhizobium and finally control. The treatment prepared from biogas slurry with inoculum Trichoderma + Rhizobium showed the fast composting and decomposition than other combinations. The harvested vermicomposts were higher in microbial diversity, nutrient content and showed effective antimicrobial activity towards different plant and human pathogens. Among treatments, the treatment prepared from Ageratina inoculated with the combination of Trichoderma and Rhizobium showed the higher increment of Potassium (K) content in comparison to the control. Similarly, Phosphorous $(P)$ increment was found to be higher in the treatment with Lantana inoculated with both Trichoderma and Rhizobium sp. Likewise, Nitrogen $(\mathrm{N})$ increment was found to be higher in Lantana inoculated with Rhizobium sp. In comparison to the control, organic matter was found to be in higher increment on $\mathrm{Ag}$ eratina inoculated with both Trichoderma and Rhizobium sp. Composts formed from all these combination were found to be basic in nature.

Key-words: antimicrobial properties, earthworms, microcosm, microorganisms, vermicompost

\section{INTRODUCTION}

Available organic wastes from different sources in real sense are not the waste but wealth. With the aid of macro and micro organisms, it can be converted into rich vermicompost and compost which is highly valuable natural resource for the plant nutrition. The technique of using specific kinds of earthworms and microorganisms to convert the biodegradable solid organic waste into black earthy-smelling nutrient enriched humus (Cook 2000) is vermicomposting and it stabilizes the variety of wastes. It is an efficient technique of recycling the animal waste, crops residues and agro-industrial wastes using low energy (Talashilkar et al. 1999). Simply, it is a biooxidation and stabilization of organic material involving the joint action of earthworms and microorganisms. The earthworms provide ideal temperature, $\mathrm{pH}$ and oxygen concentration 
for the speedy growth of useful bacteria and actinomycetes and thus have a higher microbial density of about 100 times greater than in surrounding soil (Subler 1998, Yami et al. 2003). It is very useful in the management of the organic wastes of the industrial areas that have been deteriorating our environment through the noxious smell. This methodology of biosolid waste management has shifted from conventional disposal strategies to conversion into value added products (Liang et al. 2003) forming different types of useful byproducts.

The vermicomposting process includes two different phases regarding the activity of earthworms: (i) an active phase during which earthworms process the organic waste, thereby modifying its physical state and microbial composition (Lores et al. 2006), and (ii) a maturation- like phase marked by the displacement of the earthworms towards fresher layers of undigested waste, during which the microbes take over the decomposition of the waste processed by the earthworms (Aira et al. 2007). The efficiency towards vermicomposting depends upon the age, species of earthworms and also the foods that are placed during the feeding. Eisenia foetida is the best converter of bio wastes into vermicompost. During vermicomposting, the earthworms maintain aerobic conditions in the organic wastes through proper mixing. Moreover, the biochemical process is enhanced by microbial decomposition of the substrate in the intestines. The earthworms convert a portion of the organic present in the wastes into worm biomass and excrete undigested/partially-digested matter as worm cast, which are rich in nutrient source (Benitez et al. 1999). The earthworms also enhance the biological activity in the soil by improving the environment suitable for microbes (Mulongoy et al. 1989).

Nepal is potential for composting and vermicomposting (Pradhan and Tamrakar 1999). Large quantities of organic wastes are produced from different sectors viz., agriculture and horticulture, agro-industries and as municipal waste. Vermicomposting technology is a great potential on the solid waste management which is environmental friendly and productive by reducing biodegradable solid waste, while in another hand it will benefit the marginal farmers in rural and suburban areas by producing organic manure and is likely to substitute the chemical fertilizer's demand. Biocomposting of solid waste brings about stabilization of the organic matter and effectively reduces pathogen concentrations in sludges to very low levels (Burge et al. 1987). However, absolute removal of pathogens becomes difficult to achieve and many survives the composting process (Sidhu et al. 2001). This paper basically aims to study the effectiveness of different substrate degradation enhancing fungi, Trichoderma and Rhizobium at the time of vermicomposting with the aid of earthworms, Eisenia foetida.

\section{MATERIALS AND METHODS}

Assemblage of Materials: The required materials for bedding were assembled from several places adjoining to Satdobato, Khumaltar, Lalitpur, Nepal. Different plant materials such as Lantana camara L. and Ageratina adenophora (Spreng.) King and H. Rob. L. were collected from Chobhar, Lalitpur, Nepal. Bio-gas slurry (75\% moisture content) and rice straw (dried) were collected from Chapagaun, Lalitpur, Nepal.

Structuring of Beds: Buckets were uniformly pored at the bottom and on the sides for good aeration. $100 \mathrm{gm}$ of dried chopped rice straw (2 inches long) was placed in each bucket. Lantana and Ageratina powders, biogas slurry and saw dust each of $100 \mathrm{gm}$ were placed 
in different buckets. A control set of experiment was run in parallel for every treatment. The buckets were kept moist and were placed in the laboratory at $24 \pm 2{ }^{\circ} \mathrm{C}$ for a period of $120 \mathrm{~d}$ away from the direct sunlight. There were four replicate containers for each treatment, giving a total of 64 dishes.

Treatment Combinations: 4 treatments inoculums $\times 4$ substrates $\times 4$ replications $=64$ combinations

Earthworm and Microorganism Inoculation: Twenty five numbers of morphologically similar earthworms were added for the initiation of the experiment in every bucket except the control set. Similarly, $5 \mathrm{ml}$ of microorganism's suspension $\left(10^{7} \mathrm{cfu} / \mathrm{ml}\right.$ bacteria and $1 \times 10^{6}-5 \times 10^{6}$ spores $/ \mathrm{ml}$ fungi) were added in each bucket. Biodegradable solid wastages especially the fruits, except the limes were continuously feed at every fifteen days till the last of the experimentation. The addition of the kitchen and fruit wastes were done and regularly stirred for the uniform degradation of the material. Care was taken regularly to ensure that the buckets are not devoid of food to feed for the developing earthworms.

Earthworm's Number: Counting of the earthworms was done at each month interval starting from the first month of feeding till the last. Four months later, after the whole wastages (feeding) turned blackish, the harvesting of the vermicompost was done.

Microfloral Diversity: Microbial diversity of the vermicompost and compost were done by serial dilution method followed by agar plating method in Nutrient Agar (NA), Potato Dextrose Agar (PDA) and Starch Casein Agar (SCA) for bacteria, fungi and actinomycetes respectively. Bacteria and actinomycetes were identified according to latest edition of Bergey's Manual of Determinative Bacteriology (Holt et al.1994). Actinomycetes were identified by their delayed appearance of dry, firm and tenacious colonies (Cross 1976). Morphologically, they were identified by cover slip culture method (Kawato and Shinobu 1959). Further identification was done by biochemical tests (Collins et al. 1989). Fungal colonies were identified on the basis of colony morphology, hyphae, asexual spores and sexual spores by cellophane tape method and cotton blue staining method (Aneja 1993, Alexopolus and Mims 1962).

The antimicrobial and antifungal properties of the obtained vermicompost solution and isolated microorganisms were performed against different human and plant pathogenic bacteria and fungi.

\section{RESULTS AND DISCUSSION}

Vermicompost samples were blackish moist and highly porous with the smell of earth. Different range of microbial diversity (bacteria, fungi and actinomycetes) was found to be present within small microcosm (vermicompost). The dominant microbial organisms were bacterial strains followed by fungi and actinomycetes which are similar to the work of Yami et al. (2003). Bacteria such as Bacillus sp., Pseudomonas sp., Micrococcus sp., Azotobacter sp., Beijerinckia sp. were isolated, where as the fungal isolates include Aspergillus sp., Penicillium sp., Mucor sp., Rhizopus sp., Fusarium sp., Geotrichum sp. etc. The isolated actinomycetes were Streptomyces sp., Micromonospora sp. The presence of Fusarium sp. is found to be an active organism in the organic matter decomposition in vermicompost (Mori et al. 2000). They also 
produce growth promoting substances called as 'gibberellins' that enhance other beneficial microorganisms in soil (ISSAC 1999). Curvularia lunata and Geotrichum candidum have the ability to metabolize organic compounds (Daigel et al.1999)

The beneficial microorganisms found in vermicompost made the compost nutrients rich which is valuable for better plant growth. Aspergillus sp. are capable of degrading an enormous variety of substance to use them as food because of the large number of enzymes they produce (Alexopolus and Mims 1962). Mucor and Rhizopus produced different kinds of acids such as citric acid, succinic acid, oxalic acid and other chemicals that help in the degradation of the wastes. Cellulolytic fungi such as Alternaria hemicola, Fusarium sp., Aspergillus niger and cellulolytic bacteria such as Bacillus circulans, Cellulomonas uda and Micrococcus roseus present in vermicompost were found to decompose the organic substances by secreting the different types of secondary metabolites.

Table 1. Multiplication of earthworms at different months with different substrates and treatments.

\begin{tabular}{|c|c|c|c|c|c|}
\hline \multirow{2}{*}{$\begin{array}{l}\text { Different } \\
\text { treatments }\end{array}$} & \multirow[t]{2}{*}{ Month } & \multicolumn{4}{|l|}{ Substrates * } \\
\hline & & Lantana & Ageratina & Biogas slurry & Sawdust \\
\hline Control & $\begin{array}{l}1,2,3 \\
\text { and } 4\end{array}$ & 0 & 0 & 0 & 0 \\
\hline \multirow{4}{*}{$\begin{array}{l}\text { Trichoderma } \\
\text { sp. }\end{array}$} & 1 & $17.00 \pm 6.21$ & $10.50 \pm 7.00$ & $26.50 \pm 4.50$ & $19.75 \pm 3.59$ \\
\hline & 2 & $20.50 \pm 4.02$ & $21.50 \pm 5.25$ & $31.50 \pm 4.50$ & $40.50 \pm 3.87$ \\
\hline & 3 & $26.75 \pm 3.30$ & $28.25 \pm 6.70$ & $36.75 \pm 4.34$ & $42.50 \pm 2.88$ \\
\hline & 4 & $29.25 \pm 3.86$ & $29.50 \pm 6.80$ & $39.25 \pm 4.19$ & $43.50 \pm 2.64$ \\
\hline \multirow[t]{4}{*}{ Rhizobium sp. } & 1 & $19.00 \pm 6.21$ & $10.00 \pm 5.47$ & $22.25 \pm 3.304$ & $20.00 \pm 2.16$ \\
\hline & 2 & $23.75 \pm 5.12$ & $15.50 \pm 2.08$ & $24.75 \pm 3.50$ & $44.50 \pm 2.88$ \\
\hline & 3 & $26.75 \pm 2.87$ & $20.75 \pm 2.36$ & $37.5 \pm 4.434$ & $45.75 \pm 2.75$ \\
\hline & 4 & $29.00 \pm 2.94$ & $24.25 \pm 2.62$ & $41.5 \pm 4.20$ & $47.50 \pm 3.10$ \\
\hline \multirow{4}{*}{$\begin{array}{l}\text { Trichoderma } \\
\text { sp.+ Rhizo- } \\
\text { bium sp. }\end{array}$} & 1 & $19.00 \pm 5.59$ & $12.25 \pm 6.02$ & $22.25 \pm 4.57$ & $17.00 \pm 4.96$ \\
\hline & 2 & $24.25 \pm 10.27$ & $18.00 \pm 4.96$ & $20.75 \pm 4.27$ & $19.50 \pm 4.65$ \\
\hline & 3 & $29.50 \pm 8.22$ & $25.75 \pm 4.99$ & $33.75 \pm 6.50$ & $23.75 \pm 4.57$ \\
\hline & 4 & $32.50 \pm 7.937$ & $29.50 \pm 4.20$ & $40.00 \pm 6.16$ & $30.25 \pm 5.37$ \\
\hline
\end{tabular}


${ }^{*} x \pm S D(n=4)$

The earthworm numbers were found to be significantly increasing from the initial of the experiment till the last. Several red cocoons were present in the vermicompost. Earthworm numbers were significantly high in the treatment using saw dust provided with Rhizobium ( $x=47.5$ ) which was followed by biogas slurry with Rhizobium ( $x=41.5$ ), Lantana with both Trichoderma and Rhizobium ( $x=32.5)$, Ageratina with Trichoderma + Rhizobium $(x=29.5)$ and control (Table 1$)$. This work is dissimilar to the work of Pant and Yami (2008); they found saw dust to be worst for the earthworm's multiplication. For rapid earthworm multiplication, saw dust did not play vital role, other factors such as good aeration, addition of other wastes made the saw dust to be favorable for the better reproducing environment for the earthworms. Using of substrate such as Lantana and Ageratina were found to have the least number of earthworms. The extracts Lantana and Ageratina showed the high antagonistic properties against bacterial and fungal isolates (Shrestha et al. 2009, Bhattarai and Shrestha 2009) which is found to be toxic for the earthworm multiplication. So it may be highly toxic for the earthworm multiplication.

Table 2. Change in the weight of buckets with substrates at different months.

\begin{tabular}{|l|l|l|l|l|l|}
\hline \multirow{2}{*}{$\begin{array}{l}\text { Different } \\
\text { treatments }\end{array}$} & Months & \multicolumn{3}{|l|}{ Substrates* } \\
\cline { 2 - 6 } & & Lantana & Ageratina & Biogas slurry & Sawdust \\
\hline \multirow{2}{*}{ Control } & 1 & $0.855 \pm 0.196$ & $1.093 \pm 0.130$ & $0.945 \pm 0.017$ & $0.784 \pm 0.075$ \\
\cline { 2 - 6 } & 2 & $0.830 \pm 0.082$ & $0.785 \pm 0.102$ & $0.769 \pm 0.071$ & $0.963 \pm 0.161$ \\
\hline & & & & & \\
\hline $\begin{array}{l}\text { Trichoderma } \\
\text { sp. }\end{array}$ & 1 & $0.961 \pm 0.034$ & $0.995 \pm 0.058$ & $0.981 \pm 0.096$ & $1.045 \pm 0.085$ \\
\cline { 2 - 6 } & 2 & $0.851 \pm 0.113$ & $0.762 \pm 0.107$ & $0.830 \pm 0.141$ & $1.129 \pm 0.083$ \\
\hline & & & & & $1.094 \pm 0.060$ \\
\hline Rhizobium sp. & 1 & $0.964 \pm 0.046$ & $0.990 \pm 0.133$ & $1.018 \pm 0.092$ & $1.071 \pm 0.195$ \\
\cline { 2 - 6 } & 2 & $0.755 \pm 0.141$ & $0.751 \pm 0.141$ & $0.810 \pm 0.102$ & \\
\hline \multirow{2}{*}{$\begin{array}{l}\text { Trichoderma } \\
\text { sp.+ Rhizo- } \\
\text { bium sp. }\end{array}$} & 1 & $1.025 \pm 0.170$ & $0.926 \pm 0.068$ & $1.163 \pm 0.484$ & $1.121 \pm 0.152$ \\
\cline { 2 - 6 } & 2 & $0.810 \pm 0.077$ & $0.861 \pm 0.036$ & $0.787 \pm 0.190$ & $1.076 \pm 0.113$ \\
\hline
\end{tabular}

${ }^{*} x \pm S D(n=4)$

Weight of the substrates and wastes were found to get reduced except on control at the end of the experiment ( $40 \mathrm{~d}$ ). This might be due to the proper utilization of various nutrients by the earthworms and decomposition of wastes by cellulolytic fungi and bacteria. The treatment prepared from biogas slurry inoculating with both Trichoderma + Rhizobium sp. showed higher reduced weight $(0.376 \mathrm{~kg})$ being the better composting, followed by Ageratina inoculated with Trichoderma, Lantana inoculated with Rhizobium + Trichoderma, saw dust inoculated with Trichoderma and control. That indicates the presence of cellulolytic microorganisms in 
the slurry and spores of Trichoderma contributing effectively for the fast decomposition of the vermicompost (Table 2).

Isolated organisms from vermicompost and their solution showed the antagonistic properties towards the bacterial and fungal isolates. Among the tested 14 bacterial isolates Escherichia coli, Staphylococcus aureus, Klebsiella pneumoniae, Salmonella typhi, Shigella sp. and Shigella dysenteriae F44DH were susceptible towards the vermicompost solution. Similarly, among four fungal isolates Fusarium moniliforme was also susceptible for this solution which is similar to the work of Manandhar and Yami (2008). Pseudomonas sp. produce different kinds of hydrolytic enzymes that was responsible for the decomposition of organic compounds. Except degradation, Pseudomonas sp. showed antibiotic properties that plays a defensive role for the bio-controlling mechanisms of diseases.

Table 3. Nutrient analysis of the vermicompost.

\begin{tabular}{|c|c|c|c|c|c|}
\hline \multirow{2}{*}{$\begin{array}{l}\text { Different } \\
\text { treatments }\end{array}$} & \multirow[t]{2}{*}{ Parameters } & \multicolumn{4}{|c|}{ Green manures used as substrates* } \\
\hline & & Lantana & Ageratina & Biogas slurry & Sawdust \\
\hline \multirow[t]{5}{*}{ Control } & OG & 4.06 & 3.96 & 4.14 & 3.61 \\
\hline & $\mathrm{pH}$ & 9.1 & 7.3 & 9.0 & 7.8 \\
\hline & $\mathrm{N}$ & 0.16 & 0.18 & 0.14 & 0.16 \\
\hline & $\mathrm{P}$ (kg/hectare) & 554.12 & 1042.12 & 1002.12 & 636.41 \\
\hline & $\mathrm{K}(\mathrm{kg} / \mathrm{hectare})$ & 38756.23 & 1083.86 & 17732.68 & 10284.20 \\
\hline \multirow{5}{*}{$\begin{array}{l}\text { Trichoderma } \\
\text { sp. }\end{array}$} & OG & 6.25 & 4.07 & 4.59 & 4.29 \\
\hline & $\mathrm{pH}$ & 8.5 & 8.9 & 8.3 & 8.3 \\
\hline & $\mathrm{N}$ & 0.31 & 0.20 & 0.23 & 0.21 \\
\hline & $\mathrm{P}$ (kg/hectare) & 663.53 & 1359.84 & 1114.08 & 1196.00 \\
\hline & $\mathrm{K}(\mathrm{kg} / \mathrm{hectare})$ & 52426.00 & 32427.84 & 23705.28 & 22890.24 \\
\hline \multirow[t]{5}{*}{ Rhizobium sp. } & OG & 5.95 & 4.29 & 4.56 & 5.10 \\
\hline & $\mathrm{pH}$ & 9.6 & 8.0 & 9.1 & 8.0 \\
\hline & $\mathrm{N}$ & 0.30 & 0.21 & 0.23 & 0.26 \\
\hline & $\mathrm{P}$ (kg/hectare) & 1032.17 & 1359.84 & 1359.84 & 745.45 \\
\hline & $\mathrm{K}(\mathrm{kg} / \mathrm{hectare})$ & 50549.28 & 14306.40 & 19075.20 & 16213.92 \\
\hline
\end{tabular}




\begin{tabular}{|l|l|l|l|l|l|}
\hline $\begin{array}{l}\text { Trichoderma } \\
\text { sp. +Rhizo- }\end{array}$ & $\mathrm{OG}$ & 4.44 & 5.19 & 4.86 & 4.59 \\
\cline { 2 - 6 } bium sp. & $\mathrm{pH}$ & 8.5 & 8.4 & 7.9 & 8.0 \\
\cline { 2 - 6 } & $\mathrm{N}$ & 0.22 & 0.26 & 0.24 & 0.23 \\
\cline { 2 - 6 } & $\mathrm{P}(\mathrm{kg} /$ hectare $)$ & 1196 & 1196.00 & 1359.84 & 950.25 \\
\cline { 2 - 6 } & $\mathrm{K}(\mathrm{kg} /$ hectare $)$ & 41965.44 & 32427.84 & 55318.08 & 15260.16 \\
\hline
\end{tabular}

${ }^{*} \mathrm{OG}$ : Organic matter, $\mathrm{pH}$ : Negative logarithm of Hydrogen ion concentration, $N$ : Nitrogen, $P$ : Phosphorous, K: Potassium

*Values represent the mean of four replications of each

The harvested vermicompost were higher in nutrients content. In comparison to the control, the treatment prepared from biogas slurry inoculated with both Trichoderma + Rhizobium showed better increment (55318.08), followed by Ageratina inoculated with both Trichoderma + Rhizobium, Lantana camara with Trichoderma and finally saw dust with Trichoderma (Table 3). The hydrolysis of cellulose by cellulolytic microorganisms occurs mainly through the concentrated action of several hydrolytic enzymes (Coughlan 1985). Cellulose enzyme complex decomposes cellulose into disaccharides, cellobiase to glucose that can be easily be assimilated as a carbon source. Fungi such as Aspergillus sp. Fusarium sp. and Geotrichum $\mathrm{sp}$. and bacteria such as Micrococcus sp., Pseudomonas sp. and Bacillus sp. are phosphate solubilizing microorganisms. They play a key role in the conversion of insoluble phosphate to the soluble form which is highly indispensible for the plant growth.

Similarly, P increment was found to be higher (1196.00) in that treatment which was prepared from Lantana inoculated with both Trichoderma + Rhizobium, followed by saw dust with Trichoderma, biogas slurry inoculated with both Trichoderma + Rhizobium and Ageratina inoculated with both Trichoderma + Rhizobium (Table 3). Lantana with Rhizobium, biogas slurry treated with both Trichoderma + Rhizobium, saw dust with Rhizobium and Ageratina with Trichoderma + Rhizobium. This finding was similar to the work of the Yami et al. (2003), Pant and Yami (2008), Subler et al. (1998).

Table 4. Assay of vermicompost against different pathogenic bacterial strains.

\begin{tabular}{|l|l|l|}
\hline SN & Organisms & Zone of Inhibition (ZOI, $\mathbf{~ m m})$ \\
\hline 1. & Escherichia coli & 35 \\
\hline 2. & Staphylococcus aureus & 30 \\
\hline 3. & Klebsiella pneumoniae & 25 \\
\hline 4. & Salmonella typhi & 13 \\
\hline 5. & Shigella sp. & 20 \\
\hline 6. & Shigella dysentriae F44D1 & 18 \\
\hline 7. & Bacillus subtilis & -- \\
\hline 8. & Proteus mirabilis & -- \\
\hline
\end{tabular}




\begin{tabular}{|l|l|l|}
\hline 9 & Salmonella paratyphi & -- \\
\hline 10 & Acinetobacter sp. & -- \\
\hline 11 & Enterococcus faecalis & -- \\
\hline 12 & Citrobacter freundi & -- \\
\hline 13 & Pseudomonas aeruginosa & -- \\
\hline 14 & Shigella dysentriae1002 & -- \\
\hline
\end{tabular}

Likewise, Nitrogen $(\mathrm{N})$ content was found to be in higher increment in the inoculum of Trichoderma sp. with Lantana as substrate $(0.31 \%)$, followed by slurry inoculated with both Trichoderma + Rhizobium, saw dust with Rhizobium and Ageratina inoculated with both Trichoderma + Rhizobium. Except control, all vermicomposts harvested from different treatments showed the higher NPK contents which was similar to the work of the Yami et al. (2003), Pant and Yami (2008), Subler et al. (1998). It means bacteria and fungi played pivotal role for the decomposition of organic wastes and conversion in valuable nutrients. The formation of $\mathrm{N}_{2}$ fixing bacteria such as Azotobacter, Beijerinckia and Derxia produced slime, which helps for the aggregation of the soil. Inoculation of Azotobacter sp. in the vermicompost causes decrease in C: $\mathrm{N}$ ratio (Sing et al. 2000) and increase in $\mathrm{N}_{2}$ content significantly (Kumar and Singh 2001).

As far as the nutrient compositions are concerned, the $\mathrm{pH}$ of the every set of buckets was found to be very alkaline (>7.0). The highest value for $\mathrm{pH}$ was recorded on the inoculums provided with Rhizobium sp. alone with Lantana followed by biogas slurry using as substrate. The minimum value was recorded for control treatment with Ageratina substrate followed by sawdust on the same.

The organic matter was found to be highest (6.25) in the treatment of Trichoderma sp. alone with Lantana used as substrate followed by the inoculums of the Rhizobium sp. (5.95) on the same substrate. The least value for organic matter (4.07) was recorded for the inoculums of Trichoderma with Ageratina substrate followed by the control treatment (4.13). In a sum, using of the different inoculums do harbor good nutrient contents then the control treatments.

Vermicomposting could be widely used for the stabilizing and recycling of agricultural wastes and domestic wastes reducing the bulk and level of pollution at the generation site itself. It can be used as biocontrol agent and best organic fertilizer for producing organic vegetables, organic fruits and ornamental plants. Since vermicompost produces high population of beneficial microflora its application to cultivated land will also increase their population increasing soil fertility.

\section{ACKNOWLEDGEMENTS}

We would like to thank Ms. Bijaya Laxmi Maharjan and Mr. Rishi Baniya for their great help. Thanks to the NAST family who provided the laboratory to conduct this research.

\section{REFERENCES}

Aira, M., F. Monroy and J. Domínguez, 2007. Microbial biomass governs enzyme activity decay during aging of worm-worked substrates through vermicomposting. J. Environ. Qual., 36:448-452. 
Alexopoulos, C.J. and C.W. Mims,1962. Introductory mycology, Wiley Eastern Limited, New Delhi, India (3rd edition).

Aneja, K.R.,1993. Experiments in microbiology, plant pathology and tissue culture. Vishwa Prakashan, India.

Benitez, E., R. Elvira, C. Masciandaro and G.B. Ceccanti,1999. Enzyme activities as indicators of the stabilization of sewage sludges composting with Eisenia foetida. Bioresource Technology, 67:297- 303.

Bhattarai, N. and G. Shrestha, 2009. Antibacterial and antifungal effect of Eupatorium adenophorum Spreng against bacterial and fungal isolates. Nepal Journal of Science and Technology, 10:91-95.

Bhawalkar, U.S. and U.V. Bhawalkar,1993. Vermiculture biotechnology. In Thampan, P.K. (ed) Organics in soil health and crop production. Peekay Tree Crops Development Foundation, Cochin, pp 63-85.

Burge, W.D., N.K. Enkiri and D. Hussong,1987. Salmonella regrowth in compost as influenced by Substrate. Microb. Ecol., 14:243-253.

Collins, C.H., M. Patrica and P.M. Lyne,1989. Microbiological methods. Butterworth Publisher Ltd., London (6th edition).

Cook, P., 2000. Vermicomposting. Available from htpp://www.adm.gwater100cainfowast/ vermin.html.

Coughlan, M.P.,1985. The properties of fungal and bacterial cellulases with comment on their production and application. Biotechnology and Genetic Engineering Reviews, 3: 39-109.

Cross, J.,1976. Actinomycetes. In Methods in microbiology. Vol. 4. Academic Press, London, pp 234-236.

Edwards, C.A. and P.J. Bohlen,1996. Biology and ecology of earthworms. Chapman and Hill, London, New York (3rd edition).

Holt, J.G., N.R. Krieg, P.H.A. Sneath., J.T. Staley and S.T. Williams.,1994. Bergey's manual of determinative bacteriology, Williams and Wilkins, East Preston Street, Baltimore, Maryland 21202, USA (9th edition).

Kawato, M. and R. Shinobu,1959. A simple technique for the microscopical observation, Memoirs of the Osaka University liberal arts and education, 8:114.

Kumar, V. and K.P. Singh, 2001. Enriching vermicompost by $\mathrm{N}_{2}$ fixing and phosphate solubilizing bacteria. Bioresource Technology, 76(2):173-175.

Liang, C., K.C. Das and R.W. McClendon, 2003. The Influence of temperature and moisture contents regimes on the aerobic microbial activity of a biosolids composting blend. Bioresource and Technology, 86:131-137.

Lores, M., M. Gómez-Brandón, D. Pérez-Díaz and J. Domínguez, 2006. Using FAME profiles for the characterization of animal wastes and vermicomposts. Soil Biol. Biochem., 38:2993-2996.

Manandhar,T. and K.D. Yami, 2008. Biological control of Foot Rot Disease using fermented 
products of compost and vermicompost. Scientific world, 7(7): 52-57.

Mulongoy, K. and A. Bedoret,1989. Properties of worm casts and surface soil under various plant covers in the humid tropics. Soil Biology and Biochemistry, 21:197-203.

Pant, S.R. and K.D. Yami, 2008. Selective utilization of organic solid wastes by earthworm (Eisenia foetida). Nepal Journal of Science and Technology, 9:99-104.

Pradhan, M. and A. S. Tamrakar,1999. A study on the potential for vermicomposting of organic waste and its implementation. In Proceedings of Third National Conference on Science and Technology, NAST, 2:1333.

Scheu, S.,1987. Microbial activity and nutrient dynamics in earthworms casts (Lumbricidae), Biol. Fertil. Soils, 5:230-234.

Scheu, S.,1992. Automated measurement of the respiratory response of soil micro compartments: active microbial biomass in earthworm faeces, Soil Biol. Biochem., 24: 1113-1118.

Shrestha, G. and N. Bhattarai, 2009. Antagonistic study of Lantana camara L. against with pathogenic bacteria, Scientific world, 7(7):64-67.

Sidhu, J., R. A. Gibbs., G.E. Ho and I. Unkovich, 20001. The role of indigenous microorganisms in suppression of Salmonella regrowth in composted biosolids. Water Research, 35:913-920.

Simko, J.,2000. Vermicomposting experiment report. Available from http: //WwW. sawbladessoftware. com.

Singh, K. P., V. Kumar and J.S. Hooda, 2000. The effect of inoculation with E. foetida and N fixing and $\mathrm{P}$ solubilizing microorganisms on decomposition of cattle dung and crop residues, Biological agriculture and Horticulture, 18(2):103-112.

Subler, S., C.A. Edwards and J. Metzger,1998. Comparing vermicomposts and composts. BioCycle, pp 63-66.

Talashilkar, S.C., P.P. Bhangarath and V.B. Mehta,1999. Changing in chemical properties during composting of organic residues as influenced by earthworms activity. Journal of Indian Soil Science, 47:50-53.

Tiunov, A.and S. Scheu, 2000. Microbial biomass, biovolume and respiration in Lumbricus terrestris L. Cast material of different age. Soil Biol. Biochem., 32:265-275

Yami, K.D., S. Bhattarai and S. Adhikari, 2003. Vermicomposting and microflora analysis of vermicompost, vermicast and gut of red earthworms. Nepal Journal of Science and Technology, 5:121-126.

\section{AUTHOR'S ADDRESS}

\section{Bikash Baral $^{1}$ and Geeta Shrestha ${ }^{1}$}

Nepal Academy of Science and Technology (NAST),

Khumaltar, Lalitpur, Nepal

(email: bikubaral@yahoo.com)

Nabin Bhattarai ${ }^{2}$

Nepal Mega College, Babarmahal, Kathmandu 